\title{
REGARDING THE CELEBRATION OF THE SEVENTIETH BIRTHDAY OF MÁRIA IVANICS
}

\author{
Guldana Togabayeva \\ University of Szeged \\ Szeged, Hungary \\ togabayeva.guldana@gmail.com
}

The seventieth birthday commemoration of the outstanding representative of Hungarian Turkic studies, Professor Mária Ivanics, was held 11 September 2020, at 11 a.m., in the Faculty of Humanities and Social Sciences building at the University of Szeged in Hungary. Professor Ivanics's many friends, colleagues, and students gathered to congratulate her and pay tribute to her professional achievements. The Vice Dean of the faculty, Klára Sándor, Academician András Róna-Tas (in absentia), Professor Sándor Papp, and Professor István Zimonyi spoke in honor of Professor Ivanics. Among these presenters, Professor István Zimonyi, the head of the Department of Altaic Studies and the Department of Medieval History, spoke on behalf of the former department about Ivanics' academic career and presented the volume Ottomans-Crimea-Jochids: Studies in Honour of Mária Ivanics, in which leading Hungarian and foreign scholars and young researchers published papers dedicated to her. This Festschrift presents various aspects of the development of Turkic culture and languages, Turkic-Hungarian relations (including Ottoman-Hungarian relations), as well as the history and culture of the Ottoman Empire and the Golden Horde. It contains 29 works by scholars from universities in Germany, Russia, Turkey, Kazakhstan, and Hungary. The collected articles are presented in five languages - English, German, Russian, Hungarian, and Turkish.

Keywords: Mária Ivanics, Festschrift, Turkic Studies, University of Szeged, Hungary

For citation: Togabayeva G. Regarding the Celebration of the Seventieth Birthday of Mária Ivanics. Zolotoordynskoe obozrenie=Golden Horde Review. 2020, vol. 8, no. 4, pp. 838-843. DOI: 10.22378/2313-6197.2020-8-4.838-843

Acknowledgements: I would like to express my warmest thanks to Professor István Zimonyi, Doctor Raushangul Mukusheva, and Doctor Balázs Danka for helping and sharing with me the information about Professor Mária Ivanics during our meetings and discussions.

On August 31, 2020, Professor Mária Ivanics - an outstanding representative of Hungarian Turkic studies, professor of the University of Szeged, and a member of the Hungarian Academy of Sciences - celebrated her seventieth birthday. To commemorate this milestone, Professor Ivanics's many friends, colleagues, and students gathered on September 11, 2020, at 11 a.m., in the Faculty of Humanities and Social Sciences building at the University of Szeged in Hungary for a celebration in her honor.

The event began with an opening speech by Professor Klára Sándor, Vice Dean of the Faculty of Humanities and Social Sciences. On behalf of the founder of the Department of Altaic Studies at the University of Szeged, Academician András Róna-Tas, who was unable to attend the celebration, Dr. Éva Kincses-Nagy read a warm letter of congratulation. In his letter, Professor András Róna-Tas high- 
lighted Professor Ivanics's human qualities along with her scientific work. He began her story in 1973, the year the University of Szeged's administration supported creation of the Department of Altaic Studies. At that time, Professor Róna-Tas was looking for an assistant lecturer who, in addition to having outstanding academic knowledge, would also engage in those issues of Turkic studies that he did not address. At the same time, he was looking for a specialist who would fit well in a new discipline - Altaic Studies. András Róna-Tas emphasized that it was a great success for him personally and for the university that Professor Ivanics joined the team. He thanked her for joint collaborative work on the details of vocational training, due to which the Department of Altaic Studies opened its doors to its first students in September 1974. Professor Róna-Tas also noted that working with Professor Ivanics was always easy and cloudless. She had the magical ability to solve difficult issues in the work sphere. He expressed his deepest respect for Mária Ivanics for their joint work and wished her good health, creative inspiration, and separately asked for further assistance in the department's work.

After the congratulations of Professor András Róna-Tas, Professor Sándor Papp, head of the Historical Doctoral School at the University of Szeged, gave a congratulatory speech. Then Professor István Zimonyi, head of the Department of Altaic Studies and the Department of Medieval History, spoke about Professor Ivanics's scientific career and presented her with a Festschrift, a volume titled $O t$ tomans-Crimea-Jochids: Studies in Honour of Mária Ivanics [3]. Finally, Professor Ivanics thanked all those who could come in person and all the contributors to the Festschrift.

In the Festschrift Ottomans-Crimea-Jochids: Studies in Honour of Mária Ivanics, leading Hungarian and foreign researchers in Turkic and Ottoman studies paid tribute to Professor Ivanics's scientific achievements. The Festschrift presents 29 works by scientists from Germany, Russia, Turkey, Kazakhstan, and, of course, Hungary (Eötvös Loránd University, University of Debrecen, and University of Szeged). Articles are presented in five languages - English, German, Russian, Hungarian, and Turkish - and they address various aspects of the development of Turkic cultures and languages, Turkic-Hungarian relationships including OttomanHungarian relationships, and the history and culture of the Ottoman Empire and the Golden Horde.

The Festschrift opens with an article by Klára Agyagási in Russian " $\mathrm{K}$ вопросу о хронологии изменения $-\mathrm{d}(\mathrm{r})->-\delta(\mathrm{r})->-\mathrm{y}(\mathrm{r})-$ в волжско-булгарских диалектах". This article examines the change of the intervocal $-d(r)->-y(r)$ - and provides two authoritative scientists' opinions about these changes - András Róna-Tas and Johannes Benzing.

In the article "On discourse types and clause combining in Däftär-i Čingiz nāmä”, Professor Éva Csató and Professor Lars Johanson present a description of five discourse types and types of clause combining devices employed in the volume Däftär-i Čingiz-nāmä as a response to Professor Ivanics's invitation to further study of the manuscript. In the end, instead of drawing conclusions, they urge scholars to continue Turkic studies in both philological and linguistic areas and to cooperate with colleagues from different countries.

In another article based on the Däftär-i Čingiz-nāmä, "Московский Чаган хан", Vadim Trepavlov presents the appearance of Čagan khan in Däftär-i Čingiz nāmä as the result of a combination of historical situations formed over 
several centuries among the Turkic peoples. Čagan/ Tsagaan/ Sagaan is the Mongolian form of the word "white", which is found in other Turkic sources as "Aq khan". The scholar agrees with Mária Ivanics's opinion that use of the epithet "white" to the Russian tsar and addition of the word "khan" to "white" testifies to Russian rulers' artificial legitimation.

Academician András Róna-Tas dedicated a symbolic article "A birthday present for the Khitan Empress". Before this article's publication, a draft version was presented to the readers and subscribers on the professor's page on Academia.edu, a social network for collaboration among scientists for comments and notes. The article concerns inscriptions written in Khitan Small Script on a jade jar. According to Professor Róna-Tas, the jar was a birthday present to the Khitan Empress from the Khitan Khan, and the article offers a graphic, phonological, and linguistic analysis of its text.

In the same vein, Doctor Éva Kincses-Nagy offers nine Crimean and Dobrujan Tatar words meaning "gift" in her article "Nine Gifts".

The language instructor of Kazakh, Raushangul Mukusheva, presents the article "The presence of shamanism in Kazakh and Hungarian folklore". She finds numerous ancient shamanistic elements in Kazakh and Hungarian folklore based on motifs of Kazakhs' pre-Islamic beliefs and preconquest Hungarians' worldview.

Doctor Balázs Danka, in "A misunderstood passage of Qādir 'Ali-beg Jālāyirî’s Jāmī at-Tawārī $\chi$ " considers the translation into the Kazakh language by scholars Rabiga Syzdykova and Mambet Koigeldiev of the passage from the "Compendium of Chronicles" by Qādir 'Ali-beg in Volga-Turkī literary language. $\mathrm{He}$ analyzes that translation and provides a new Latin transcription with the passage's translation into English.

In the article "On some taboo words in Yeniseian", Doctor Bayarma Khabtagaeva discusses fifteen loanwords from the Yeniseian and Altaic languages to the taboo words category.

In "Was the Chinggisid khan an autocrat? Reflections on the Foundations of Chinggisid authority", Professor Uli Schamiloglu, Head of the Department of Kazakh Language and Turkic Studies at Nazarbayev University (Kazakhstan), examines some aspects of the basis of the Chinggisid state from its creation through the Crimean Khanate in the seventeenth century. In particular, he elucidates the established concept of an autocrat with unlimited power.

The final article in the Festschrift is titled "Edil in Däftär-i Čingiz-nāmä" and presented in English by Professor István Zimonyi, who considers the name of the hydronym Etil/ Edil (Volga) in Däftär-i Čingiz-nāmä. In this article, Professor Zimonyi provides historical background for the names Etil/ Edil, illustrating with maps from the fifteenth to seventeenth century and listing various sources where components of Etil/ Edil were used.

Two articles in the Festschrift are presented in German: "Bemerkungen zu der neu gefundenen Dede Korkut-Handschrift, mit einer Übersetzung der dreizehnten Geschichte" by Hendrik Boeschoten and "Entstehung eines auf Osmanisch verfassten Friedenskonzepts Ein Beitrag zu der Vorgeschichte des Frienden von Eisenburg 1664" by Hajnalka Tóth. One article titled "Kaukázusi török népek kálváriája a népdalok tükrében" is written in Hungarian by Éva Csáki. Mustafa S. Kaçalin wrote "Joannes Lippa: Türkçe hayvan masalları" in Turkish. The rest of the articles 
were written in English and Russian. In addition to the scientists mentioned above, the Festschrift also contains articles by such prominent researchers and young scientists as Henryk Jankowski, Mihály Dobrovits, Géza Dávid, Sándor Papp, Pál Fodor, Funda Güven, Benedek Péri, Claudia Römer, Beáta Varga, Il'ya Zaytsev and Reshat Aliev, László Balogh, Tasin Gemil, Csaba Göncöl, Murat Işık, and, finally, Barış Yılmaz. All dedicated their articles to Professor Mária Ivanics.

Mária Ivanics was born on August 31, 1950, in Budapest. She grew up in Gyömrö, a town near Budapest where her parents lived. After graduating from school in 1968, she entered Eötvös Loránd University (Budapest) where she studied the Russian language and literature. Later, she became interested in Turkic studies. In those years, the department had two separate full-time programs: general Turkic studies and Ottoman studies. Mária Ivanics chose the latter field under the supervision of Gyula Káldy-Nagy. In 1972, she spent one semester at Leningrad State University (now St. Petersburg State University) a requirement for all students of Russian philology.

In 1973, she defended her Master of Arts thesis on seventeenth-century Transylvanian and Crimean Tatar connections. After graduation, she began teaching Russian at a secondary school in Budapest. That year, the Department of Altaic Studies opened at József Attila University (now the University of Szeged), where she was invited to be an assistant lecturer by Professor András Róna-Tas, the head of the department. In 1976, Mária Ivanics successfully defended her doctoral dissertation Crimean Tatar Documents in Hungary. From 1980 until 1986, she relocated to Vienna (Austria) with her husband Imre Ress, the historian-archivist who was Hungarian deputy at the Austrian State Archives during those years. Professor Mária Ivanics regularly visited the archives in Vienna and collected many and varied materials she could use in her ongoing scholarly work. In addition, she attended Professor Anton Cornelius Schaendlinger's seminars and further developed her skill in reading complex Ottoman texts.

In 1992, Professor Ivanics defended her dissertation The Crimean Khanate in the Fifteen Years' War 1593-1606, earning the "Candidate of Science" degree from the Hungarian Academy of Science. In 2009, she defended her dissertation The Nomadic Prince in the Däftär-i Čingiz-nāmä: The Nomadic Mirror for Princes and received the title "Doctor of Science" from the Hungarian Academy of Sciences; thereafter, she was elevated to full professorship. From 2008 to 2015, she headed the Department of Altaic Studies at the University of Szeged. From 2012 to 2017, Professor Ivanics led the MTA-SZTE Turkological Research Group of the Hungarian Academy of Sciences and the University of Szeged in the project Cultural Heritage of the Turkic Peoples. In addition to lecturing and tutoring at the department, she is involved in editorial and organizational work. Professor Ivanics has been the editor of the Oriental series Körösi Csoma Kiskönyvtár published by the Hungarian Academy of Sciences since 2005 in Hungarian and co-editor of the series Studia Uralo-Altaica published in Szeged since 2008. Every week, she traveled to Szeged from Budapest by train, a 2.5-3 hour trip, to lecture at the University. She has taught undergraduate, graduate, and doctoral students, and under her supervision, Hungarian and foreign students have written and continue to write their dissertations.

Since 1989, Mária Ivanics has been a board member of the Körösi Csoma Society, a scholarly society of Hungarian Oriental scholarship. Since 1993, she has 
been a member of the Oriental Studies Committee of the Hungarian Academy of Sciences. She became a board member of the Hungarian-Turkish Society of Friendship at its foundation in 1989, and from 2008 to 2017, she filled the post of vice-president. Professor Ivanics holds such outstanding awards as the Géza Kuun Award, the Ferenc Szakály Award, and the Award for Hungarian Higher Education. During her scientific work, she has received various research grants.

Her initial research topic was the Ottoman Empire and later, the Crimean Khanate, which played an important role in Hungarian history during the sixteenth and seventeenth century. Since Crimean Khanate traditions go back to the Golden Horde, the spectrum of Professor Ivanics's interests spilled over to the successor khanates of the Golden Horde, in particular to the Volga region. One of her latest books is Hatalomgyakorlás a steppén - A Dzsingisz-náme nomad világa [2]. This work's main theme is the anonymous narrative source of the seventeenth-century Däftär-i Čingiz-nāmä [1], which was published in a carefully prepared critical edition with facsimile, transcription into Latin script, and dictionary in 2002, in collaboration with the late Professor Mirkasym A. Usmanov (Kazan).

Professor Ivanics's fluency in German, Russian, and Turkish enabled her to represent Hungarian Oriental studies at international scientific conferences and workshops. Her research studies have been published in Hungarian, German, Russian, English, and Turkish. She is in close contact with the turcologists and historians of Russia, Tatarstan, and Kazakhstan. We - numerous students, friends, and colleagues of Professor Ivanics spread all over the world-value both her scientific achievements and human qualities. We all congratulate and wholeheartedly wish our highly respected "Tanárnö" good health, bright ideas, and further scientific and creative projects.

\section{REFERENCES}

1. Ivanics M. and Usmanov M.A. Das Buch der Dschingis-Legende (Däftär-i Čingiznāmä), Vol. I: Vorwort, Einführung, Transkription, Wörterbuch, Faksimiles. Szeged: Department of Altaic Studies, University of Szeged, 2002. 324 p. (In German)

2. Ivanics M. Hatalomgyakorlás a steppén - A Dzsingisz-náme nomad világa [Wielding Power on the Steppe - The Nomadic World of Chinggis-name]. Budapest: MTA Bölcsészettudományi Kutatóközpont, Történettudomány Intézet, 2017. 336 p. (In Hungarian)

3. Zimonyi I. (ed). Ottomans - Crimea - Jochids: Studies in Honour of Mária Ivanics. Szeged: Department of Altaic Studies, University of Szeged, 2020. 373 p.

About the author: Guldana Togabayeva - $\mathrm{PhD}$ student at the Department of Altaic Studies, University of Szeged (2, Szeged Egyetem Str., Szeged 6722, Hungary). Email: togabayeva.guldana@gmail.com 


\title{
О ТОРЖЕСТВЕННОМ МЕРОПРИЯТИИ, ПОСВЕЩЕННОМ 70-ЛЕТИЮ МАРИИ ИВАНИЧ
}

\author{
Гулдана Тогабаева \\ Сегедский университет \\ Сегед, Венгрия \\ togabayeva.guldana@gmail.com
}

11 сентября 2020 года в 11 часов утра в здании факультета гуманитарных и социальных наук Сегедского университета в Венгрии состоялось торжественное поздравление с 70-летием выдающегося представителя венгерской тюркологии, профессора Марии Иванич. На торжественном мероприятии собрались ее друзья, коллеги и ученики. Выступили с речью заместитель декана Клара Шандор, академик Андраш Рона-Таш (заочно), профессор Шандор Папп, профессор Иштван Зимони. От имени кафедры алтаистики выступил заведующий кафедрой алтаистики и кафедрой средневековой истории профессор Иштван Зимони. Он осветил научную деятельность Марии Иванич и торжественно преподнес подарок в виде юбилейного сборника статей, в котором ведущие венгерские и зарубежные ученые, молодые исследователи и соискатели посвятили ей коллективный труд «Османы-Крым-Джучиды: Исследования в честь Марии Иванич».

В этом сборнике представлены различные аспекты развития тюркских культур и языков, тюркско-венгерские отношения, в том числе османско-венгерские отношения, история и культура Османской империи и Золотой Орды. В сборнике представлены 29 работ ученых из Германии, России, Турции, Казахстана, и конечно же, Венгрии: Будапештский университет, Дебреценский университет и Сегедский университет. Статьи представлены на пяти языках: английском, немецком, русском, венгерском и турецком.

Ключевые слова: Мария Иванич, юбилейный сборник, тюркология, Сегедский университет, Венгрия

Для цитирования: Togabayeva G. Regarding the Celebration of the Seventieth Birthday of Mária Ivanics // Золотоордынское обозрение. 2020. Т. 8, № 4. С. 838-843. DOI: $10.22378 / 2313-6197.2020-8-4.838-843$

Сведения об авторе: Гулдана Тогабаева - $\mathrm{PhD}$ студент кафедры алтаистики, Сегедский университет (6722, ул. Эдьетем, 2, Сегед, Венгрия). Email: togabayeva.guldana@gmail.com 